Book Review

\title{
Rodriguez, Agustin Martin G., Governing the Other: Exploring the Discourse of Democracy in a Multiverse of Reason ${ }^{1}$
}

Franz Giuseppe F. Cortez

$\mathrm{D}$ irecting pedestrians to avoid jaywalking, the sign "Bawal tumawid dito, Gamitin ang underpass" is common in many roads of Mega Manila in the Philippines. Equally common is the violation of this traffic rule. For example, in one particular area, almost all, if not all pedestrians including myself violate the same sign and perhaps do not mind disobeying it each and every day, rain or shine. Walking some more meters to use the underpass would be a waste of time, energy and effort. There was even one instance when a very angry pedestrian challenged a motorist to a fistfight because the motorist, probably irritated by the pedestrian's non-compliance to the traffic rule, shouted at him. This is an interesting case of the law-violator getting mad with the law-abider. But why? What is going on in the mind of these pedestrians (including myself)? What accounts for this seeming "ungovernability"?

The answer will not be surprising for anyone who would observe closely the situation there. The street can be crossed by walking a few steps. There is less traffic on that area compared to other roads; thus, the danger of crossing that road is so slight. With the rush of city-life, it is highly impractical to walk some 300 hundred meters more just to abide faithfully to a traffic sign that turns out to be insignificant. The sign is not justified for the law-violators. It is a one-sided rule imposed by a particular rationality that does not take into consideration the rationalities of those whose lives are affected by that rule.

Agustin Martin Rodriguez's Governing the Other: Exploring the Discourse of Democracy in a Multiverse of Reason explores this issue of "ungovernability" of the Filipinos. By "ungovernable" he means:

${ }^{1}$ Quezon City: Ateneo de Manila University Press, 2009. 234 pp.

2 "Do not cross. Use the underpass." 
... that we are an anarchic people who are concerned merely with the individual, familial and community needs; that we are incapable of existing in solidarity as a nation without undermining the collective national will for the collective good. ${ }^{3}$

Rodriguez theorizes that the root of this seeming ungovernability of the majority is that the Philippine nation, its government, and many of its institutions are not justified especially to the dominated and marginalized majority of the Filipinos. He declares:

... the ungovernable majority of Filipinos belong to rationalities alien to the dominant rationality which defines governance structures. It is difficult for the marginalized Other to fall in line or to allow themselves to engage the transcendent national whole because they come from a life world, a system of valuation, a horizon of understanding, or a mode of reasoning other than the elite-defined rationality. ${ }^{4}$

With this hypothesis, Rodriguez states that the purpose of the book is "to understand the meaning of just governance in a nation composed of a multiplicity of communities with competing conceptions of the good."

The book is a collection of essays written from 2001 to 2009. Most of the essays first appeared in academic journals. Rodriguez reflects on themes such as governance, democracy, discourse, justice, law, rationalities, popular education, politics and political parties. These ideas are important not only for students and lovers of philosophy but also for political scientists, sociologists, educators, legal luminaries, community organizers, civil society groups, and those who work on behalf of the marginalized. Rodriguez's major philosophical anchorages are the social philosophers John Rawls and Jürgen Habermas. Their thoughts are mainly exposed in Chapter 2 entitled "The Ground of Solidarity: From Consensus to Discourse." Throughout the book, the reader will sense that the author goes back to the main thoughts of these thinkers, especially the ones argued by Habermas.

Through this book, Rodriguez joins the probably short list of Filipino thinkers who see philosophy as a tool for the analysis of the social and political life in the Philippines. Possibly seeing the urgency of bringing down highly philosophical sophistications in the context of the lived experiences of the Filipinos,

\footnotetext{
${ }^{3}$ Rodriguez, Governing the Other, 2 .

${ }^{4}$ Ibid., 4.

${ }^{5}$ Ibid., 1 .
} 
Rodriguez turns the readers' attention to a promising brand of philosophizing meaningfully in the Philippines. Rodriguez explains his method of study in the following:

In this series of reflections we will dialogue with the work of political scientists, sociologists, and anthropologists who study Philippine political culture, as well as with advocates of Philippine democratic reform, in order to reflect on their praxis and experience. ${ }^{6}$

Rodriguez does not only consult the philosophical writings of Habermas, Rawls, Derrida, Levinas and Gandhi. He also uses the texts from the fields of political science, law and sociology. He also studies cases and retrieves data through immersion in some communities.

Reading this book, the followers of the Frankfurt School's Critical Theory tradition may also be reminded of the famous 1931 inaugural address of Max Horkheimer, one of the main precursors of Critical Theory, when he envisioned a social philosophy that is multidisciplinary and interdisciplinary in approach. ${ }^{7}$ Horkheimer, in a related essay, reiterates that Critical Theory "never aims simply at an increase of knowledge as such. Its goal is man's emancipation from slavery." Following this tradition, Rodriguez' Governing the Other is not only significant for the furtherance of abstract knowledge and motherhood statements. Rather, it provides a philosophical base and explores practical steps in approaching some urgent problems that the Philippine society faces. Specifically, it serves as a response to Demeterio's call for treading "the pathway of critique" to catalyze the re-emergence of critical Filipino philosophy in an opportune time when democratic spaces are more accessible for various rationalities in spite of the many material and ideological constraints. And while Rodriguez engages in a critique of Philippine society, his book also becomes a living testament of the Filipino disciples of philosophy's ability to transcend the boundaries defined by our long history of intellectual slavery and the continuing story of neocolonial imposition where doing philosophy is not spared. Indeed, this book is a valuable contribution to critical Filipino philosophy. It is another way of effectively doing philosophy for a populace that craves and yearns for philosophy not just as ivory tower thinking but as a tool for social critique.

${ }^{6}$ Ibid., 1 .

${ }^{7}$ Cf. Max Horkheimer, "The State of Contemporary Social Philosophy and the Tasks of an Institute for Social Research," in Stephen Eric Bronner \& Douglas MacKay Kellner, Critical Theory and Society: A Reader (New York: Routledge, 1989).

${ }^{8}$ Max Horkheimer, Critical Theory: Selected Essays, trans. by Matthew J. O'Connell and others (New York: Continuum, 2002), 246.

(C) 2012 Franz Giuseppe F. Cortez

http://www.kritike.org/journal/issue 11/cortez june2012.pdf

ISSN 1908-7330 
Another strong point of the book is Rodriguez's ability to explain in simple but not simplistic terms the difficult concepts of Habermas and Rawls. As many in the field of philosophy in the Philippines know, Rodriguez has a reputation not only for being a lively and persuasive speaker but also for his simplicity and clarity of explanation. This book is an extension of this simplicity combined with eloquence. Through concrete applications, clear explanations and comprehensible arguments, Rodriguez brings down from the clouds Rawls' notions of overlapping consensus, the fact of pluralism, the imaginary original position, the veil of ignorance and justice as fairness. The same is true with Habermas' notions of discourse, rationality, communicative action, and ideal speech situation. Even the incidental discussions on Jacques Derrida's notion of hospitality, Emmanuel Levinas' idea of infinite responsibility and Mahatma Gandhi's ahimsa prove to be valuable. Thus, the student of philosophy is given a practical anchorage while the nonstudent of philosophy is provided with access to the philosophical enterprise.

Another achievement of the book is Rodriguez's insights on the tension that exists between the seeming inevitability of the physical and social world's destruction and the reason to hope for its salvation. Rodriguez asks: "As the world races toward complete environmental destruction, should we also see the death of the hope for a just social order?" With the overpowering and irresistible tide of the violent forces of oppression and injustice (read: neoliberalism, neoimperialism, global capitalism, hyperconsumerism), fatalism, cynicism and hopelessness seem to be the most reasonable option (or non-option?) for the people of the periphery and those who champion their cause. Taking his cue from the innocent "turn to the transcendent" of his 8-year old daughter, Rodriguez's reflection on hope is also illuminated and enriched by the thoughts of Levinas and Gandhi.

Rodriguez's turn to the transcendent represents a break with Jürgen Habermas, his main inspiration. Habermas may be optimistic and hopeful about the possibilities opened to human society in the discursive democratic system. But it seems he remains relatively neutral or even ambivalent about the role of religion and transcendence on this. ${ }^{10}$ It is in the same vein that Raymond Morrow and Carlos Alberto Torres assess Habermas' non-propensity to theology.

${ }^{9}$ Rodriguez, Governing the Other, 220.

10 "Communicative reason neither announces the absence of consolation in a world forsaken by God, nor does it take it upon itself to provide any consolation ... As long as no better words for what religion can say are found in the medium of rational discourse, it will coexist abstemiously with the former, neither supporting it nor combating it." Jürgen Habermas, Postmetaphysical Thinking: Philosophical Essays, trans. by W.M. Hohengarten (Cambridge, MA and London: MIT Press, 1992), 145. Also cf., Michelle Dillon, "The Authority of the Holy Revisited: Habermas, Religion, and Emancipatory Possibilities," in Sociological Theory, 17:3 (Nov., 1999), 290-306. Here, Dillon criticizes Habermas' notion of religion as inimical to rational discourse.

(C) 2012 Franz Giuseppe F. Cortez

http://www.kritike.org/journal/issue 11/cortez june2012.pdf

ISSN 1908-7330 
But Habermas remains resistant to pursuing (such)
theological questions even though his theory of
communicative action has stimulated the rethinking of
fundamental theology and has been viewed as
complementary to liberation theology....Yet theological
questions remain inevitable for those caught up in
transforming the way of life through which their identity was
formed. The vast majority of oppressed groups retain strong
religious beliefs as part of their popular culture. ${ }^{11}$

It is to Rodriguez's credit that in spite of taking off from a Habermasian rational discourse, he dares to tread the path where Habermas is probably reluctant to pursue, thus transcending the possible limits of this social philosopher. Hence, with Rodriguez's approval, we can start or continue working with critical hope for social justice and peace, in spite of great difficulty "inside the belly of the beast"12 because of the possibility of "a theological moment in critical theory." 13

But this essay does not only exalt Rodriguez's work; it also looks into its failing and raises some questions. One of which is the bypassing of the theme of "governing the people of the Center" and focusing too much on the issue of governing the Other or the people of the margins. Without the intention of illegitimately going outside the scope of what is being critiqued, it seems that this act of sidestepping of the ungovernable Center emanates from the author's outlook about the people of the periphery. For Rodriguez, the Other, or the "hungry, exploited, oppressed, and treated cheaply"14 is "the least able to govern and most ungovernable, as well as the most disadvantaged, by our governance system." ${ }^{15}$ Indeed, the Other has always been the most disadvantaged in the Philippine society. But, is he/she the least able to govern? More so, is the Other the most ungovernable? Inasmuch as Rodriguez has the best of intentions in excavating the root of ungovernability, the excavation does not reach the bottom when the Same is bypassed, giving the impression that it is a given fact that the people at the Center are more governable. The marginalized violate the law because most of the time, it is for their survival and/or the result of the vicious cycle of oppression. Rodriguez's analysis of the drama of the sidewalk vendors is a case in point. ${ }^{16}$ Meanwhile, the

\footnotetext{
${ }^{11}$ Raymond A. Morrow and Carlos Alberto Torres, Reading Freire and Habermas: Critical Pedagogy and Transformative Social Change (New York : Teachers College Press, 2002), 159.

12 Peter McLaren, "Educating for Social Justice and Liberation," in <http://www.zcommunications.org/educating-for-social-justice-and-liberation-by-peter-mclaren $>$, April 26, 2012.

${ }^{13}$ Morrow and Torres, Reading Freire and Habermas, 159.

${ }^{14}$ Rodriguez, Governing the Other, 4.

${ }^{15}$ Ibid., 3.

${ }^{16}$ Ibid., 5 ff.
} 
people at the Center monopolize the formulation of the law, understand the law completely, study and analyze it, and then subvert it to their advantage. The telenovela of the recent impeachment of the chief justice of the Philippines is a fitting starting point in proving this. ${ }^{17}$ The effect of this "rationality" - of the ungovernability of the Other and the contrary notion of the governability of the Same - is not unimportant because false generosity and uncritical action initiated by well-intentioned members of the Center may flow from it. Furthermore, it may lead to a psycho-social response from the Other, an internalization of and adherence to the imposed rationality: "Kami na naman ang may problema. Siguro, kami talaga ang problema." ${ }^{18}$ That is why different sites must become educational/pedagogical sites for the conscientization of the people at the Center and the periphery alike. The challenge, therefore, for other Filipino scholars who are interested in critical Filipino philosophy is to fill this lacuna and consider an indepth study of the issue of "governing the Same."

Some questions can also be raised to further discuss the themes of Rodriguez's book. First, an interested reader may also explore the relationship between governability and nationalism. Rodriguez claims that one of the reasons for the Filipinos being ungovernable is the lack of sense of nationhood. ${ }^{19}$ But why should an individual really care for national interest? What is there in the caring for the nation that is reasonably comparable to caring for the family, the relative or the immediate neighbor? Isn't it that the notion of nationalism and patriotism is also part and parcel of the rationalities of the dominant order? How do we account for the case of an overseas Filipino worker who is convinced of a nationalistic stirring by leaving the country while a social critic sees it the other way around? Interestingly, Kathleen Abowitz and Jason Harnish, in their article about citizenship discourses, discovered that Jurgen Habermas sketches the history of the term "nation." According to these two researchers, Jurgen Habermas, in his essay entitled "Citizenship and National Identity,"

... documents the history of the word nation, tracing its roots in Roman times to Natio, the goddess of birth and origin. Until the middle of the 18th century, and later in many cases, nations were communities of people linked by heredity. "Hereditary nationality gave way to an acquired nationalism" after the French Revolution, and that form of nationalism

\footnotetext{
${ }^{17}$ On May 29, 2012, Renato Corona, the chief justice of the Philippines was judged guilty by the Philippine Senate sitting as an impeachment court.

18 "Here we go again. Maybe, we are really the problem."

${ }^{19}$ Rodriguez, Governing the Other, $1 \mathrm{ff}$.

(C) 2012 Franz Giuseppe F. Cortez

http://www.kritike.org/journal/issue 11/cortez june2012.pdf

ISSN 1908-7330 
"was able to foster people's identification with a role which demanded a high degree of personal commitment. ${ }^{20}$

Nationalism, just like democracy, is a Western construct, an expression of a particular rationality. With Rodriguez, therefore, we still question: whose rationality is favored when we call for nationalism and patriotism?

In an interview, the philosopher of language Noam Chomsky asks: "Why should a system of power offer opportunities to people who are trying to undermine it?"21 This question would haunt any supporter of the Habermasian discursive democracy. One does not expect the Center to give in to the margins, to allow a smooth entry of the children of the periphery into the systems of the Center, to reach the ideal speech situation. Zeus Leonardo, a critical educator, even suggests that the ideal speech situation is prone to become "ideological speech situation," ${ }^{22}$ a systematic distortion of the former. In the concrete, it means that often when the Center thinks of discourse and dialogue, it is also at the same time an encounter of "daya" (deception) at "lugi" (to be in the losing end). Usually, the Other is deceived and thus, loses in the end. And so, in spite of the many merits of Rodriguez's book, and in the spirit of Critical Theory's insistence on a philosophy "that does not find peace within itself," ${ }^{\prime 23}$ we are still in a continuing search for ways of attaining justice and peace without resorting to the totalizing ideology of a violent power-grab.

Department of Philosophy, University of Santo Tomas, Philippines

\section{References}

Abowitz, Kathleen and Jason Harnish, "Contemporary Discourses of Citizenship," in Review of Educational Research, 76:4 (Winter, 2006).

Dillon, Michelle, "The Authority of the Holy Revisited: Habermas, Religion, and Emancipatory Possibilities," in Sociological Theory, 17:3 (1999).

Habermas, Jürgen, Postmetaphysical Thinking: Philosophical Essays, trans. by W.M. Hohengarten (Cambridge, MA and London: MIT Press, 1992), 145.

Horkheimer, Max, "The State of Contemporary Social Philosophy and the Tasks of an Institute for Social Research," in Stephen Eric Bronner \& Douglas MacKay Kellner, Critical Theory and Society: A Reader (New York: Routledge, 1989).

\footnotetext{
${ }^{20}$ Kathleen Abowitz and Jason Harnish, "Contemporary Discourses of Citizenship," in Review of Educational Research, 76:4 (Winter, 2006), 653-690. (2000), 34-37.

${ }^{21}$ Pepi Leistyna, "Avoiding the tragedy that awaits us," in Educational Researcher, 29:3

${ }^{22}$ Zeus Leonardo, "The Souls of White Folk: critical pedagogy, whiteness studies, and globalization discourse," in Race Ethnicity and Education, 5:1 (2002).

${ }^{23}$ Horkheimer, Critical Theory, 252.

(C) 2012 Franz Giuseppe F. Cortez http://www.kritike.org/journal/issue 11/cortez june2012.pdf ISSN 1908-7330 
Critical Theory: Selected Essays, trans. by Matthew J. O'Connell and others (New York: Continuum, 2002),

Leistyna, Pepi, "Avoiding the tragedy that awaits us," in Educational Researcher, 29:3 (2000).

Leonardo, Zeus, "The Souls of White Folk: critical pedagogy, whiteness studies, and globalization discourse," in Race Ethnicity and Education, 5:1 (2002).

McLaren, Peter, "Educating for Social Justice and Liberation," in $<$ http://www.zcommunications.org/educating-for-social-justice-andliberation-by-peter-mclaren>, April 26, 2012.

Morrow, Raymond A. and Carlos Alberto Torres, Reading Freire and Habermas: Critical Pedagogy and Transformative Social Change (New York: Teachers College Press, 2002).

Rodriguez, Agustin Martin G., Governing the Other: Exploring the Discourse of Democracy in a Multiverse of Reason (Quezon City: Ateneo de Manila University Press, 2009). 